Check for updates

Cite this: J. Mater. Chem. C, 2021, 9, 7474

Received 23rd March 2021,

Accepted 4th May 2021

DOI: $10.1039 / d 1 t c 01330 k$

rsc.li/materials-c

\section{Narrow-band red phosphors of high colour purity based on $\mathrm{Eu}^{3+}$-activated apatite-type $\mathrm{Gd}_{9.33}\left(\mathrm{SiO}_{4}\right)_{6} \mathrm{O}_{2} \dagger$}

\author{
Melissa M. Rodríguez-García, (D) a Aleksandar Ciric, (D) ${ }^{\mathrm{b}}$ Zoran Ristic, (D) ${ }^{\mathrm{b}}$ \\ J. A. Gareth Williams, (D) Miroslav D. Dramićanin (D) *b and \\ Ivana Radosavljevic Evans (D) *a
}

\begin{abstract}
A series of new red phosphors based on apatite-type gadolinium silicate host, $\mathrm{Gd}_{9.33-x} \mathrm{Eu}_{x}\left(\mathrm{SiO}_{4}\right)_{6} \mathrm{O}_{2}$ $(0.03<x<1.87)$, have been synthesised and analysed. The phosphors show excellent chemical and thermal stability, losing only $10 \%$ of their emission intensity at $150{ }^{\circ} \mathrm{C}$ (working LED temperature) relative to that at room temperature through the electric dipole-dipole interaction. They exhibit efficient $\mathrm{Eu}^{3+}$ narrow-band red emission (quantum yield up to 75\%; full-width at half-maximum (FWHM) $=7 \mathrm{~nm}$; $\mathrm{CIE}$ colour coordinates $x=0.65, y=0.35$ ) of exceptional colour purity $(94.2 \%)$, and the host can be heavily doped with $\mathrm{Eu}^{3+}$ (up to 10 at\%) without concentration quenching of the emission. Variable-temperature powder X-ray diffraction, photoluminescence spectroscopy and Judd-Ofelt analysis of the phosphors' radiative properties reveal the favourable influence of the structural properties of the apatite-type host on the efficiency and thermal stability of the $\mathrm{Eu}^{3+}$-activated $\mathrm{Gd}_{9.33}\left(\mathrm{SiO}_{4}\right)_{6} \mathrm{O}_{2}$ emission.
\end{abstract}

\section{Introduction}

The conventional technology for lighting based on incandescence or fluorescence activated by electric discharge is increasingly being replaced by more efficient and reliable white light-emitting diodes (WLEDs). There is much interest in the development of efficient WLEDs to reduce the amount of energy consumed for the new generation of ambient lighting. However, the development faces several challenges, one of which is to produce red phosphors with high chemical and thermal stability that also have high quantum yields to ensure efficient energy conversion. ${ }^{1-4}$ Phosphors for WLEDs should also possess high colour-rendering index (CRI). The issue is that the higher the CRI, the lower the luminous efficacy (the light output per unit energy), as the human visual response peaks in the green region of the spectrum. For white lighting, the best possible balance between lighting quality and efficiency is a CRI of 90, where the luminous efficacy of radiation (LER) is $408 \mathrm{~lm} \mathrm{~W}^{-1}$. For white light generated by the combination of red, green and blue emitters (RGB), the emission wavelength for the red component that maximises efficiency is at $614 \mathrm{~nm} \cdot{ }^{5-7}$ For the green

\footnotetext{
${ }^{a}$ Department of Chemistry, Durham University, Durham DH1 3LE, UK.

E-mail: ivana.radosavljevic@durham.ac.uk

${ }^{b}$ Institute of Nuclear Sciences "Vinča," - The National Institute of the

Republic of Serbia, University of Belgrade, P.O. Box 522, 11001 Belgrade,

Serbia. E-mail: dramicanin@gmail.com

$\dagger$ Electronic supplementary information (ESI) available. See DOI: 10.1039/ d1tc01330k
}

component, where the human eye response is stronger, narrow emission linewidths are not critical for efficiency, nor are they for the blue component, which makes only a low contribution to white light. On the other hand, the red component linewidth is critical and must be narrower than $20 \mathrm{~nm}$ in order to minimise spillover into deeper red, where the human visual response drops very steeply. ${ }^{8}$

Some trivalent lanthanide ions have $\mathrm{f}-\mathrm{f}$ emission bands in the visible spectrum. $\mathrm{Eu}^{3+}$ is one such ion: its hypersensitive ${ }^{5} \mathrm{D}_{0} \rightarrow{ }^{7} \mathrm{~F}_{2}$ transition is often used to generate light at about $617 \mathrm{~nm}$. ${ }^{9}$ Of the seven possible ${ }^{5} \mathrm{D}_{0} \rightarrow{ }^{7} \mathrm{~F}_{J}$ transitions, the ${ }^{5} \mathrm{D}_{0} \rightarrow{ }^{7} \mathrm{~F}_{1}$ (at around $593 \mathrm{~nm}$ ) is the only one with purely magnetic dipole character. This transition is allowed by the Laporte selection rule but, in low symmetry environments, it tends to show weaker emission than the ${ }^{5} \mathrm{D}_{0} \rightarrow{ }^{7} \mathrm{~F}_{2}$ of the remaining six transitions of electric dipole character (parity-forbidden). ${ }^{10}$ A further overview of these transitions (shown in Fig. 1) is given in Table S1 (ESI $\dagger){ }^{9}$

The emission spectra of $\mathrm{Eu}^{3+}$ ions strongly depend on the symmetry of the site in the host lattice, which is why $\mathrm{Eu}^{3+}$ can be used as a spectral probe for the point symmetry of the doping site. If the $\mathrm{Eu}^{3+}$ is located on an inversion centre, the ${ }^{5} \mathrm{D}_{0} \rightarrow{ }^{7} \mathrm{~F}_{1}$ transition dominates over the ${ }^{5} \mathrm{D}_{0} \rightarrow{ }^{7} \mathrm{~F}_{2}$ transition, resulting in bright orange luminescence. ${ }^{11}$ The ${ }^{5} \mathrm{D}_{0}$ and ${ }^{7} \mathrm{~F}_{0}$ levels cannot undergo splitting, but each of the ${ }^{7} \mathrm{~F}_{J}$ levels $(J=1$ to 6) can be split into up to $2 J+1$ Stark sub-levels according to the symmetry (Table S2, ESI $\dagger$ ) leading to fine structure. 


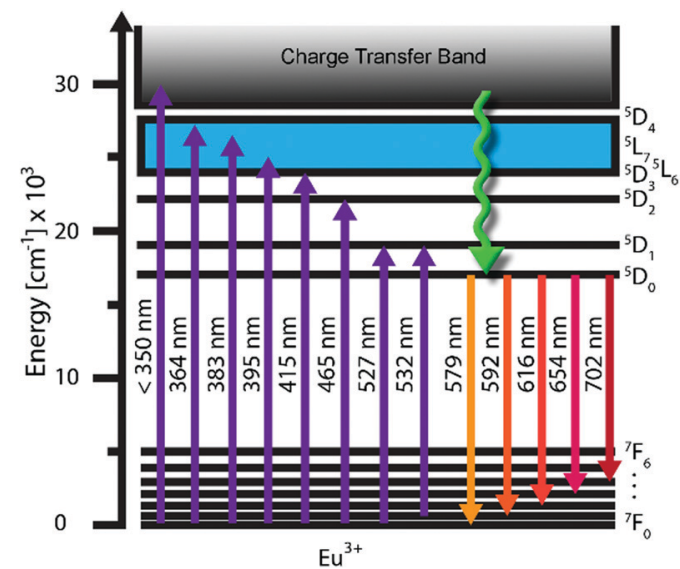

Fig. 1 Energy level diagram for $\mathrm{Eu}^{3+}$ ion showing the relevant transitions.

The ${ }^{5} \mathrm{D}_{0} \rightarrow{ }^{7} \mathrm{~F}_{0}$ transition (at around $580 \mathrm{~nm}$ ) comprises only a single band and thus can be used to determine the minimum number of different sites occupied by the $\mathrm{Eu}^{3+}$ including possible silent transitions, if the spectral resolution is sufficiently high.

The symmetry of the doping site that the $\mathrm{Eu}^{3+}$ ion occupies will dictate the broadening of the emission peak. Selected illustrative examples of $\mathrm{Eu}^{3+}$-doped narrow-band red phosphors are given in Fig. 1.

In Table 1, these materials are arranged based in the order of increasing full-width at half-maximum (FWHM) measured for the ${ }^{5} \mathrm{D}_{0} \rightarrow{ }^{7} \mathrm{~F}_{2}$ emission. The red phosphor with the smallest FWHM of $3 \mathrm{~nm}$ is $\mathrm{Y}_{2} \mathrm{MoO}_{6}: \mathrm{Eu}^{3+}$ with an emission maximum at $611 \mathrm{~nm},{ }^{12}$ whilst $\mathrm{Y}_{2} \mathrm{SiO}_{5}: \mathrm{Ce}^{3+}, \mathrm{Tb}^{3+}, \mathrm{Eu}^{3+}$ shows $\lambda_{\max }=612 \mathrm{~nm}$ and FWHM $=5 \mathrm{~nm}^{13}$ Amongst apatite-type phosphors, an FWHM of $7 \mathrm{~nm}$ has been reported for $\mathrm{Sr}_{2}\left(\mathrm{La}_{1-x} \mathrm{Eu}_{x}\right)_{8}\left(\mathrm{GeO}_{4}\right)_{6} \mathrm{O}_{2}$, for which $\lambda_{\max }=612 \mathrm{~nm}^{14}$

In this paper we describe the preparation and properties of a new series of narrow-band red phosphors based on apatite-type gadolinium silicate, $\mathrm{Gd}_{9.33}\left(\mathrm{SiO}_{4}\right)_{6} \mathrm{O}_{2}$. This material has been selected as the host because it can absorb energy efficiently in the near-UV region through the ${ }^{8} \mathrm{~S} \rightarrow{ }^{6} \mathrm{P}_{5 / 2,7 / 2}$ transition of the
$\mathrm{Gd}^{3+}$ sensitiser. $^{24}$ Its suitability as a host has already been reported in studies of white-emitting phosphors. ${ }^{25-32}$ The series of red phosphors prepared in this work adopt the general formula $\mathrm{Gd}_{9.33-x} \mathrm{Eu}_{x}\left(\mathrm{SiO}_{4}\right)_{6} \mathrm{O}_{2}$ (with $x=0.03,0.05,0.07,0.09$, $0.19,0.28,0.47,0.65,0.93,1.40$ and 1.87 , corresponding to a maximum of 20 at $\% \mathrm{Eu}^{3+}$ doping). Variable temperature powder X-ray diffraction (PXRD) and optical measurements were used to probe the structural and luminescence behaviour of the materials, with the aim of investigating concentration and thermal quenching, emission efficiency and colour purity.

\section{Experimental}

\subsection{Synthesis}

All samples were prepared using conventional solid-state synthesis. The starting materials were dried at $1200{ }^{\circ} \mathrm{C}$ and PXRD patterns were recorded to check reagent quality prior to using them in the synthesis. To prepare $2.0 \mathrm{~g}$ of each composition, stoichiometric amounts of the reagents were weighed (with a precision of $\pm 0.0001 \mathrm{~g}$ ), ground for around 30 minutes, and heated in cycles with intermittent grinding, first at $1400{ }^{\circ} \mathrm{C}$ for $100 \mathrm{~h}$ and then at $1500{ }^{\circ} \mathrm{C}$ for $200 \mathrm{~h}$.

\subsection{Powder X-Ray diffraction}

Laboratory PXRD patterns were recorded at room temperature to monitor the purity of the samples between each heating cycle. The final recorded patterns were fitted using a modified structural model of $\mathrm{Gd}_{9.33}\left(\mathrm{SiO}_{4}\right)_{6} \mathrm{O}_{2} \cdot{ }^{24}$ A Bruker AXS d8 Advance $^{33}$ diffractometer using $\mathrm{CuK} \alpha_{1,2}$ radiation and a Lynxeye detector were used to record the patterns in a $2 \theta$ range from $10^{\circ}$ to $70^{\circ}$ using a step size of $0.02^{\circ}$ and a step time of $1 \mathrm{~s}$. All PXRD data were analysed using Topas Academic software. ${ }^{34,35}$ The refined variables included the background terms, diffractometer zero point, pseudo-Voigt peak shape function parameters, unit cell parameters and isotropic atomic displacement parameters for each phase. For the variable-temperature X-ray diffraction (VTXRD), a Bruker AXS d8 Advance diffractometer with $\mathrm{CuK} \alpha_{1,2}$ radiation, a LynxEye detector and an Anton Parr HTK1200

Table 1 Optical and crystallographic properties of $\mathrm{Eu}^{3+}$-doped narrow-band red phosphors

\begin{tabular}{|c|c|c|c|c|c|}
\hline Material & $\begin{array}{l}\text { FWHM } \\
{[\mathrm{nm}]}\end{array}$ & $\begin{array}{l}{ }^{5} \mathrm{D}_{0} \rightarrow{ }^{7} \mathrm{~F}_{2} \text { emission } \\
{[\mathrm{nm}]}\end{array}$ & Wyckoff sites & Site symmetries & $\begin{array}{l}\text { Splitting of }{ }^{5} \mathrm{D}_{0} \rightarrow{ }^{7} \mathrm{~F}_{2} \\
\text { emission peak }\end{array}$ \\
\hline $\mathrm{Y}_{2} \mathrm{MoO}_{6}: \mathrm{Eu}^{3+12}$ & 3 & 611 & $4 \mathrm{e}$ and $8 \mathrm{f}$ & $C_{2}$ and $C_{1}$ & 5 peaks \\
\hline $\mathrm{Y}_{2} \mathrm{SiO}_{5}: \mathrm{Ce}^{3+}, \mathrm{Tb}^{3+}, \mathrm{Eu}^{3+13}$ & 5 & 612 & $8 f$ & $C_{1}$ & 5 peaks \\
\hline $\mathrm{Li}_{2} \mathrm{SiN}_{2}: \mathrm{Eu}^{3+15}$ & 7 & 612 & $8 c$ & $C_{1}$ & 5 peaks \\
\hline $\mathrm{Sr}_{2}\left(\mathrm{La}_{1-x} \mathrm{Eu}_{x}\right)_{8}\left(\mathrm{GeO}_{4}\right)_{6} \mathrm{O}_{2}{ }^{14}$ & 7 & 613 & $4 \mathrm{f}$ and $6 \mathrm{~h}$ & $C_{3}$ and $C_{\mathrm{s}}$ & 3 and 5 peaks \\
\hline $\mathrm{Ba}_{2} \mathrm{La}_{2.63} \mathrm{~Tb}_{0.15} \mathrm{Eu}_{0.22}\left(\mathrm{SiO}_{4}\right)_{3} \mathrm{~F}^{16}$ & 10 & 616 & $4 \mathrm{f}$ and $6 \mathrm{~h}$ & $C_{3}$ and $C_{\mathrm{s}}$ & 3 and 5 peaks \\
\hline $\mathrm{Sr}_{3} \mathrm{Gd}_{0.9} \mathrm{Na}\left(\mathrm{PO}_{4}\right)_{3} \mathrm{~F}: 0.1 \mathrm{Eu}^{3+17}$ & 10 & 615 & $2 d$ & $C_{3}$ & 3 peaks \\
\hline $\mathrm{Ba}_{2} \mathrm{Gd}_{8}\left(\mathrm{SiO}_{4}\right)_{6} \mathrm{O}_{2}: \mathrm{Eu}^{3+18}$ & 10 & 615 & $4 \mathrm{f}$ and $6 \mathrm{~h}$ & $C_{3}$ and $C_{\mathrm{s}}$ & 3 and 5 peaks \\
\hline $\mathrm{Sr}_{5}\left(\mathrm{PO}_{4}\right)_{1.9}\left(\mathrm{SiO}_{4}\right)_{0.95}: \mathrm{Eu}^{3+19}$ & 14 & 614 & $4 \mathrm{f}$ and $6 \mathrm{~h}$ & $C_{3}$ and $C_{\mathrm{s}}$ & 3 and 5 peaks \\
\hline $\operatorname{LiLaMg}(\mathrm{W}, \mathrm{Mo}) \mathrm{O}_{6}: \mathrm{Eu}^{3+20}$ & 15 & 615 & $4 g$ & $C_{2}$ & 5 peaks \\
\hline $\mathrm{Ca}_{5}\left(\mathrm{PO}_{4}\right)_{3} \mathrm{~F}: 0.04 \mathrm{Eu}^{3+21}$ & 20 & 620 & $4 \mathrm{f}$ and $6 \mathrm{~h}$ & $C_{3}$ and $C_{\mathrm{s}}$ & 3 and 5 peaks \\
\hline $\mathrm{Sr}_{4} \mathrm{La}_{6}\left(\mathrm{SiO}_{4}\right)_{6} \mathrm{~F}_{2}: \mathrm{Eu}^{3+22}$ & 25 & 615 & $4 \mathrm{f}$ and $6 \mathrm{~h}$ & $C_{3}$ and $C_{\mathrm{s}}$ & 3 and 5 peaks \\
\hline $\mathrm{Sr}_{4} \mathrm{La}_{6}\left(\mathrm{SiO}_{4}\right)_{6} \mathrm{Cl}_{2}: \mathrm{Eu}^{3+22}$ & 25 & 615 & $4 \mathrm{f}$ and $6 \mathrm{~h}$ & $C_{3}$ and $C_{\mathrm{s}}$ & 3 and 5 peaks \\
\hline $\mathrm{Gd}_{2} \mathrm{Mo}_{2} \mathrm{O}_{9}: \mathrm{Eu}^{3+11}$ & 25 & 612 & $4 \mathrm{a}$ & $C_{3}$ & 3 peaks \\
\hline $\mathrm{La}_{2} \mathrm{Mo}_{3} \mathrm{O}_{12}: \mathrm{Eu}^{3+11}$ & 25 & 615 & Three $8 f$ & $C_{1}$ & 5 peaks \\
\hline $\mathrm{La}_{2} \mathrm{Mo}_{2} \mathrm{O}_{9}: \mathrm{Eu}^{3+11}$ & 25 & 612 & $4 a$ & $C_{3}$ & 3 peaks \\
\hline $\mathrm{TiO}_{2}: \mathrm{Eu}^{3+23}$ & 27 & 610 & $2 a$ & $D_{2 \mathrm{~h}}$ & 5 peaks \\
\hline
\end{tabular}


high-temperature furnace were used. The patterns were recorded every $23.5{ }^{\circ} \mathrm{C}$ from 18 to $527{ }^{\circ} \mathrm{C}$, with an initial heating and cooling cycle to eliminate any moisture. Temperature calibration in the diffractometer furnace was performed using an alumina standard.

\subsection{Photoluminescence spectroscopy}

Photoluminescent characterisation was performed using a high-stability solid-state laser at $532 \mathrm{~nm}$ as the excitation source. An optical diffraction grating with 300 lines $/ \mathrm{mm}$ (Horiba Jobin Yvon FHR1000 monochromator) and iCCD camera (Horiba Jobin Yvon 3771) were used on the detection side. A Horiba Jobin Yvon Fluorolog-3 Model FL3-221 spectrofluorometer system was used to collect the variabletemperature emission spectra under excitation by a $450 \mathrm{~W}$ xenon lamp. Homogeneous, finely powdered samples of the materials were heated from room temperature to $475{ }^{\circ} \mathrm{C}$ with addition of MicrOptik temperature-controlled liquid nitrogen cooling/heating stage. For lifetime measurements, the radiation from the laser was modulated, and emission spectra were measured as a function of delay time from the falling edge (laser off). The Judd-Ofelt parameters and derived quantities were calculated using the JOES $^{36}$ software package.

\section{Results and discussion}

\subsection{Structural analysis}

Fig. 2 shows the Rietveld fit for the $\mathrm{Gd}_{9.30} \mathrm{Eu}_{0.03}\left(\mathrm{SiO}_{4}\right)_{6} \mathrm{O}_{2}$ compound. Corresponding fits for the $\mathrm{Gd}_{9.33-x} \mathrm{Eu}_{x}\left(\mathrm{SiO}_{4}\right)_{6} \mathrm{O}_{2}$ $(x=0.03,0.05,0.07,0.09,0.19,0.28,0.47,0.65,0.93,1.40$ and 1.87) phosphor series are provided in the ESI, $\dagger$ Fig. S1. The patterns were fitted using the structural model of the hexagonal apatite in space group $P 6_{3} / \mathrm{m}$. Small amounts of $\mathrm{Gd}_{2} \mathrm{SiO}_{5}$ (peaks marked with $\nabla$ in Fig. S1, ESI $\dagger$ ) were detected in most samples (Table S3, ESI $\dagger$ ).

In the apatite structure type, which can be described in terms of the general formula $A_{10}\left(B \mathrm{O}_{4}\right)_{6} X_{2 \pm \delta}$ (where $A$ is a larger cation, $B$ is a smaller cation, and $X$ is an anion), doping can potentially occur on two crystallographically independent A-sites on which $\mathrm{Gd}^{3+}$ is located: A1 (Wyckoff site $4 \mathrm{f}$ with site symmetry $C_{3}$ ) and A2 (Wyckoff site $6 \mathrm{~h}$ with site symmetry $C_{\mathrm{s}}$ ). The distance between the $\mathrm{Eu}^{3+}$ dopants in the material is important as the emission intensity may decrease due to the energy transfer (ET) between activator ions. Fig. 3 shows the connectivity between different $\mathrm{Gd}^{3+}$ sites, labelled Gd1 (shown as pink polyhedra) and Gd2 (shown as purple polyhedra). Fig. $3 \mathrm{a}$ and $\mathrm{b}$ shows the connectivity in the $a b$ plane, where a $\mathrm{Gd} \mathrm{O}_{6}$ trigonal prism shares all its six oxygen atoms with 7-coordinate $\mathrm{Gd}_{2} \mathrm{O}_{7}$ polyhedra and the distance between Gd1 and Gd2 sites is $\sim 4.1 \AA$. Fig. $3 \mathrm{c}$ shows the connectivity in the $c$-direction. The Gd1 sites are arranged in vertical chains formed by $\mathrm{Gd}^{1} \mathrm{O}_{6}$ trigonal prisms, sharing top and bottom faces, connected by their six oxygen atoms with two other $\mathrm{Gd} 1 \mathrm{O}_{6}$ trigonal prisms, and where the distance between neighbouring Gd1 atoms is $\sim 3.4 \AA$. Fig. 3d shows the Gd2 sites connected by two rings that share two oxygen atoms between the top and bottom layers. Each ring has three $\mathrm{Gd}_{2} \mathrm{O}_{7}$ that share corners with a central oxygen atom. The distance between Gd2 and Gd2 ranges from 4.1 to $5.6 \AA$.

\subsection{Photoluminescence of $\mathrm{Gd}_{9.33}\left(\mathrm{SiO}_{4}\right)_{6} \mathrm{O}_{2}: \mathrm{Eu}^{3+}$ materials}

Fig. 4(a) shows the photoluminescence (PL) emission spectra for the phosphors recorded under $532 \mathrm{~nm}$ excitation. PL emission spectra are typical for the $\mathrm{Eu}^{3+}$ activated compounds and consist of five narrow peaks centred at 577, 591, 614, 653, and $705 \mathrm{~nm}$ arising from the ${ }^{5} \mathrm{D}_{0} \rightarrow{ }^{7} \mathrm{~F}_{0-4}$ electronic $\mathrm{f}-\mathrm{f}$ transitions. The emission centred at $614 \mathrm{~nm}$ is due to the hypersensitive ${ }^{5} \mathrm{D}_{0} \rightarrow{ }^{7} \mathrm{~F}_{2}$ electric-dipole transition and dominates the spectrum since the $\mathrm{Eu}^{3+}$ is in non-centrosymmetric crystallographic sites: the site symmetries of the $\mathrm{Eu}^{3+}$ ions are $C_{3}(4 \mathrm{f})$ and $C_{\mathrm{s}}(6 \mathrm{~h})$. The expected splittings for the ${ }^{5} \mathrm{D}_{0} \rightarrow{ }^{7} \mathrm{~F}_{2}$ manifold are 3 and 5 for each site (as seen in Table S2, ESI $\dagger$ ), which leads to broadening of the band; however, the FWHM is only $7 \mathrm{~nm}$, such that the compound could be categorised as a narrow-band red phosphor. For the most intensely emitting composition, $\mathrm{Gd}_{8.4} \mathrm{Eu}_{0.93}\left(\mathrm{SiO}_{4}\right)_{6} \mathrm{O}_{2}$, the CIE colour coordinate of emission is $(0.65,0.35)$, Fig. $4 \mathrm{~b}$.

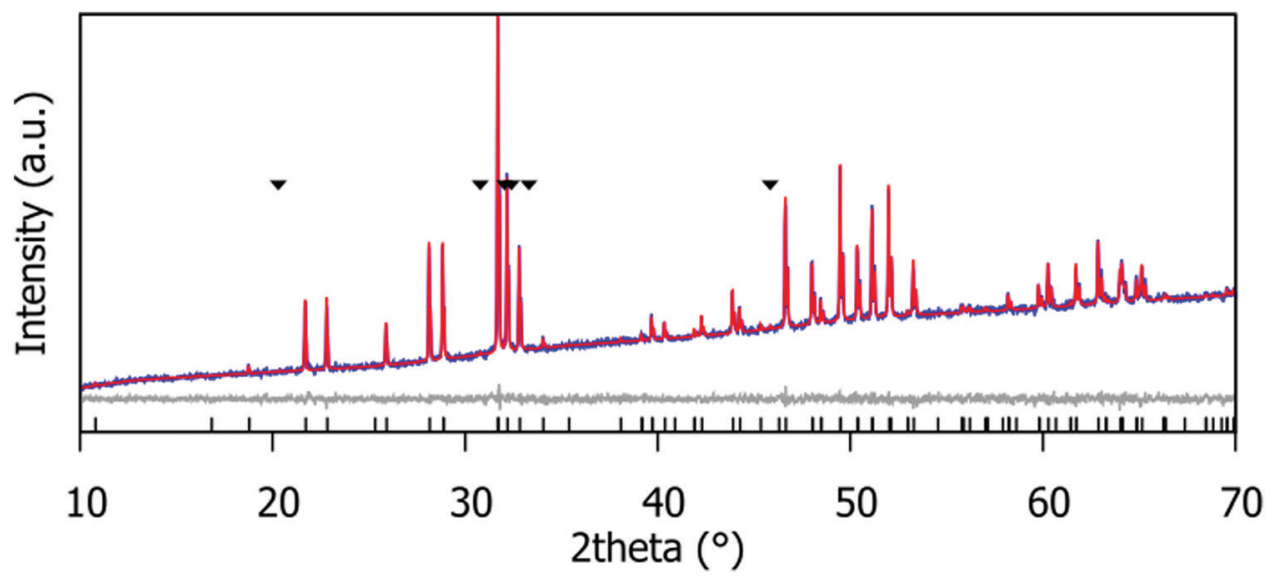

Fig. 2 Rietveld fit of the laboratory PXRD data for the $\mathrm{Gd}_{9.30} \mathrm{Eu}_{0.03}\left(\mathrm{SiO}_{4}\right)_{6} \mathrm{O}_{2}$ phosphor. $\nabla$ indicates the $\mathrm{Gd}_{2} \mathrm{SiO}_{5}$ impurity peaks; this impurity is present at $2.7(8) \%$ by weight. 
a)

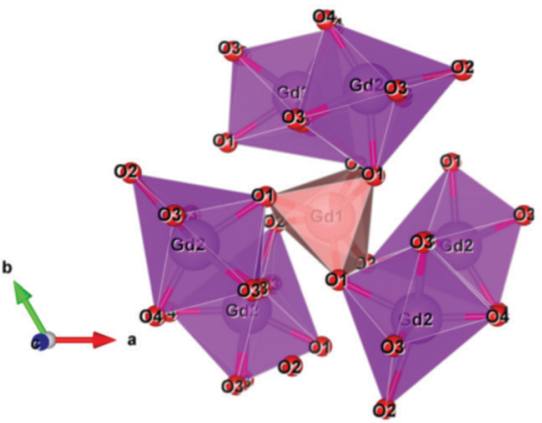

c)

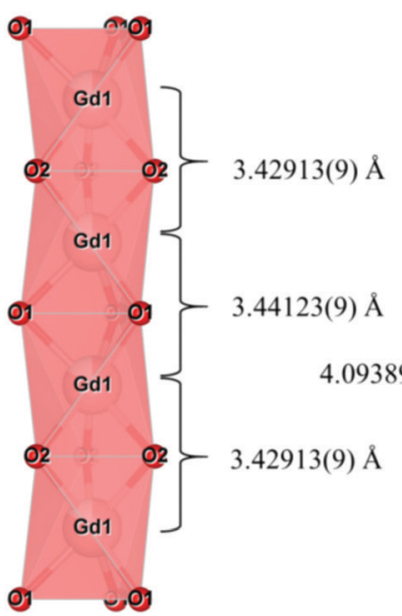

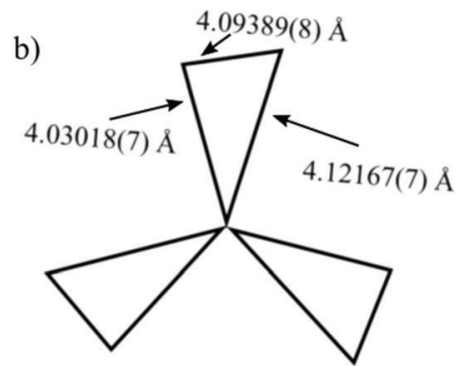

Fig. 3 (a) View of the $a b$ plane, (b) schematic of the $a b$ plane, (c) c-direction for $\mathrm{Gd} 1$ sites and (d) $c$-direction for $\mathrm{Gd} 2$ sites for the $\mathrm{Gd}_{9.33}\left(\mathrm{SiO}_{4}\right)_{6} \mathrm{O}_{2}$ structure.
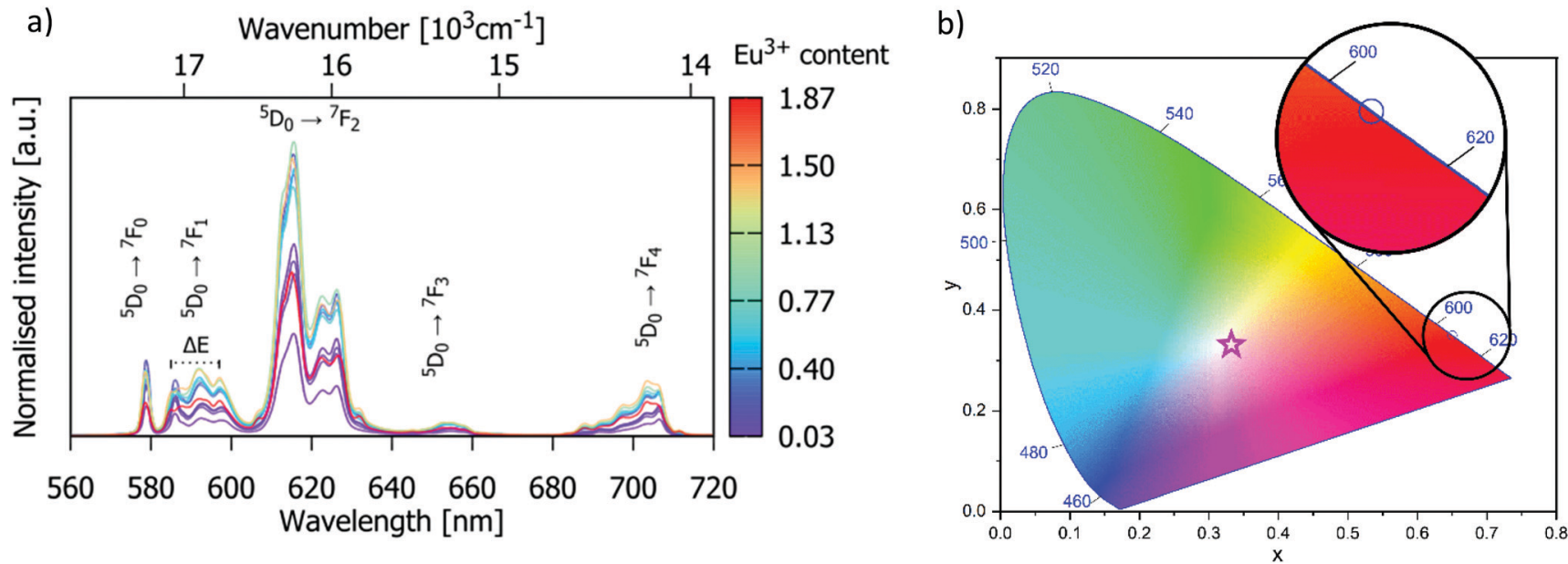

Fig. 4 (a) Room-temperature emission spectra of $\mathrm{Gd}_{9.33-x} \mathrm{Eu}_{x}\left(\mathrm{SiO}_{4}\right)_{6} \mathrm{O}_{2}(0.03<x<1.87)$ recorded under $532 \mathrm{~nm}$ excitation. (b) $\mathrm{ClE}$ chromaticity diagram showing the $\mathrm{Gd}_{8.4} \mathrm{Eu}_{0.93}\left(\mathrm{SiO}_{4}\right)_{6} \mathrm{O}_{2}$ emission colour coordinate of $(0.65,0.35)$; the star symbol represents the $\mathrm{CIE} \mathrm{E}$ achromatic point $(1 / 3,1 / 3)$.

For this phosphor composition, the colour purity (CP) is determined to be $94.2 \%$ using the following formula: ${ }^{37}$

$$
\mathrm{CP}=\frac{\sqrt{\left(x-x_{i}\right)^{2}+\left(y-y_{i}\right)^{2}}}{\sqrt{\left(x_{r}-x_{i}\right)^{2}+\left(y_{r}-y_{i}\right)^{2}}} \times 100 \%,
$$

where $(x, y)=(0.65,0.35)$ is the colour coordinate of the sample emission, $\left(x_{i}, y_{i}\right)=(1 / 3,1 / 3)$ stands for the CIE $\mathrm{E}$ (equal energy) achromatic point, and $\left(x_{\mathrm{r}}, y_{\mathrm{r}}\right)=(0.67,0.33)$ is the coordinate of the primary red colour. The $\mathrm{CP}$ of the red emission displayed by this material is superior to that of $\mathrm{SrMoO}_{4}: \mathrm{Eu}^{3+}(\mathrm{CP}=85.8 \%){ }^{38}$ 
$\mathrm{Ca}_{0.5} \mathrm{Sr}_{0.5} \mathrm{MoO}_{4}: \mathrm{Eu}^{3+}(\mathrm{CP}=89.5 \%),{ }^{39} \mathrm{NaBiF}_{4}: \mathrm{Eu}^{3+}(\mathrm{CP}=90.2 \%){ }^{37}$ and almost equal to the colour purity of ultra-heavily doped $\mathrm{Ba}_{6} \mathrm{Gd}_{2} \mathrm{Ti}_{4} \mathrm{O}_{17}: \mathrm{Eu}^{3+}(\mathrm{CP}=94.4 \%) .{ }^{40}$

\subsection{Concentration quenching of $\mathrm{Eu}^{3+}$ emission}

The dependence of the ${ }^{5} \mathrm{D}_{0} \rightarrow{ }^{7} \mathrm{~F}_{2}$ emission intensity at $614 \mathrm{~nm}$ on $\mathrm{Eu}^{3+}$ doping concentration is given in Fig. 5. The emission intensity is highest for $\mathrm{Eu}^{3+}$ concentration $x=0.93$ (which corresponds to the critical concentration $x_{\mathrm{c}}=10$ atom\% with respect to the number of $\mathrm{Gd}^{3+}$ ions), beyond which it decreases slightly for $x=1.40$, and significantly for the material containing $x=1.87$. This demonstrates that apatite-type gadolinium silicates can be heavily doped with $\mathrm{Eu}^{3+}$ to achieve intense emission, more so than $\mathrm{Sr}_{2(1-x)} \mathrm{Eu}_{2 x} \mathrm{ZnGe}_{2} \mathrm{O}_{7}$, for which high emission intensity is retained only to $x=0.05,{ }^{41}$ or $\mathrm{NaSrLa}_{1-x}\left(\mathrm{MO}_{4}\right)_{3}$, where the highest emission intensity was found at $x=0.008$ and $x=0.010$ for $\mathrm{M}=$ Mo and $\mathrm{W}$ respectively. ${ }^{42}$

The $\mathrm{Eu}^{3+}{ }^{5} \mathrm{D}_{0}$ excited state lifetimes of gadolinium silicate apatite samples activated with different amounts of $\mathrm{Eu}^{3+}$ are shown in Table S4 (ESI $\dagger$ ). The decay of the emission at $614 \mathrm{~nm}$ fits well to first-order kinetics, giving lifetimes of 1.05 to $1.35 \mathrm{~ms}$. These values are similar to those of $\mathrm{Eu}^{3+}$-doped $\mathrm{Sr}_{2} \mathrm{La}_{8}$ $\left(\mathrm{GeO}_{4}\right)_{6} \mathrm{O}_{2}{ }^{14}$ and $\mathrm{Gd}_{9.33-x-y} \mathrm{Eu}_{x} \mathrm{~Tb}_{y}\left(\mathrm{SiO}_{4}\right)_{6} \mathrm{O}_{2}{ }^{25}$ with lifetimes of 0.9 to $1.3 \mathrm{~ms}$ and 1.28 to $1.39 \mathrm{~ms}$, respectively. The lifetime decreases for $\mathrm{Eu}^{3+} x>0.93$, which is consistent with the observed intensity decrease for such compositions, and confirms that the drop-off in intensity is due to excited-state quenching (Fig. 5 and 6).

The distance between the activator ions $\left(\mathrm{Eu}^{3+}\right)$ is important as the emission intensity may decrease due to the energy transfer (ET) between activator ions. The critical distance for ET can be calculated using the following equation: ${ }^{43,44}$

$$
R_{\mathrm{c}}=2\left(\frac{3 V}{4 \pi x_{\mathrm{c}} N}\right)^{\frac{1}{3}}
$$

where $N$ and $V$ are the number of cations in the unit cell and the volume of the unit cell respectively. The critical concentration, $x_{\mathrm{c}}$, is the $\mathrm{Eu}^{3+}$ content in respect to the $\mathrm{Gd}^{3+}$ in the host at which the emission intensity starts to decrease. The concentration quenching was found to begin at doping levels $x_{\mathrm{c}}=10$ atom\% $(x=0.1)$. Using this value with $N=8$ and $V=530.75 \AA^{3}$, the critical transfer distance is calculated to be $R_{\mathrm{c}}=10.821(6) \AA$. In general, for distances $R_{\mathrm{c}}>5 \AA$, the mechanism of nonradiative energy transfer is through electric multipolar interaction. ${ }^{18}$ The character of interaction can be more closely described by Van Uitert's relationship between the emission intensity $I(x)$ and dopant concentration $x$ (valid for $\left.x \geq x_{\mathrm{c}}\right):{ }^{45}$

$$
\frac{I(X)}{X}=K \cdot\left(1+\beta \cdot X^{-\frac{Q}{3}}\right)^{-1}
$$

where $K, \beta$ and $Q$ are constants to be determined. The value of $Q$ indicates the character of multipolar interactions: $Q=6$ for dipole-dipole interactions; $Q=8$ for dipole-quadrupole interactions; and $Q=10$ for quadrupole-quadrupole interactions. The graph $\log (I / x)$ vs. $\log (x)$ is depicted in inset of Fig. 5 , the slope $-Q / 3$ is around -2 , so the value of $Q$ was found to be 6 , implying that the emission quenching mechanism in $\mathrm{Gd}_{9.33-x} \mathrm{Eu}_{x}\left(\mathrm{SiO}_{4}\right)_{6} \mathrm{O}_{2}$ occurs via dipole-dipole interactions.

\subsection{Thermal stability of the $\mathrm{Gd}_{9.05} \mathrm{Eu}_{0.28}\left(\mathrm{SiO}_{4}\right)_{6} \mathrm{O}_{2}$ phosphor}

Variable-temperature powder X-ray diffraction (PXRD) was used to assess the thermal stability of the materials prepared. Fig. 7 shows a surface plot of the 42 diffraction patterns recorded on warming and cooling between $18{ }^{\circ} \mathrm{C}$ and $527{ }^{\circ} \mathrm{C}$. The $\mathrm{Gd}_{9.05} \mathrm{Eu}_{0.28}\left(\mathrm{SiO}_{4}\right)_{6} \mathrm{O}_{2}$ phosphor does not undergo any phase transitions or abrupt changes in unit cell parameters, and it retains its crystallinity, demonstrating that it can be used in applications that require high temperature environments, e.g. $150{ }^{\circ} \mathrm{C}$, a temperature typical of a working LED.

Rietveld fitting of the different patterns was performed and the values of the lattice parameters obtained are presented in. The linear and volume thermal expansion coefficients $\alpha_{\mathrm{a}}=$ $8.87(9) \times 10^{-6} \mathrm{~K}^{-1}, \alpha_{\mathrm{c}}=5.90(1) \times 10^{-6} \mathrm{~K}^{-1}$, and $\alpha_{\mathrm{V}}=2.40(2) \times$ $10^{-5} \mathrm{~K}^{-1}$. The variation of the unit cell parameters with

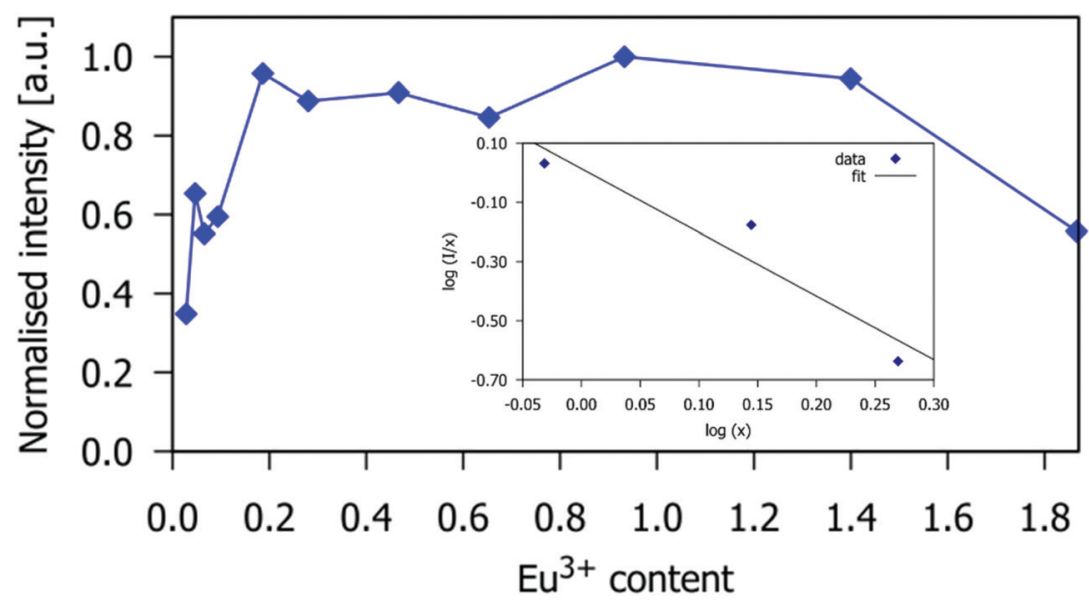

Fig. 5 The intensity of the $\mathrm{Eu}^{3+5} \mathrm{D}_{0} \rightarrow{ }^{7} \mathrm{~F}_{2}$ emission band of $\mathrm{Gd}_{9.33-x} \mathrm{Eu}_{x}\left(\mathrm{SiO}_{4}\right)_{6} \mathrm{O}_{2}$ at $614 \mathrm{~nm}$ as a function of the Eu ${ }^{3+}$ concentration. $(0.03<x<1.87)$. The intensities are normalised to the value of the highest intensity $(x=0.93)$. The inset shows the $\log _{10}\left(/ / x_{\mathrm{Eu}}\right) v s$. $\log _{10}\left(x_{\mathrm{Eu}}\right)$ plot for the Eu ${ }^{3+}$ doping concentrations larger than the critical concentration. 


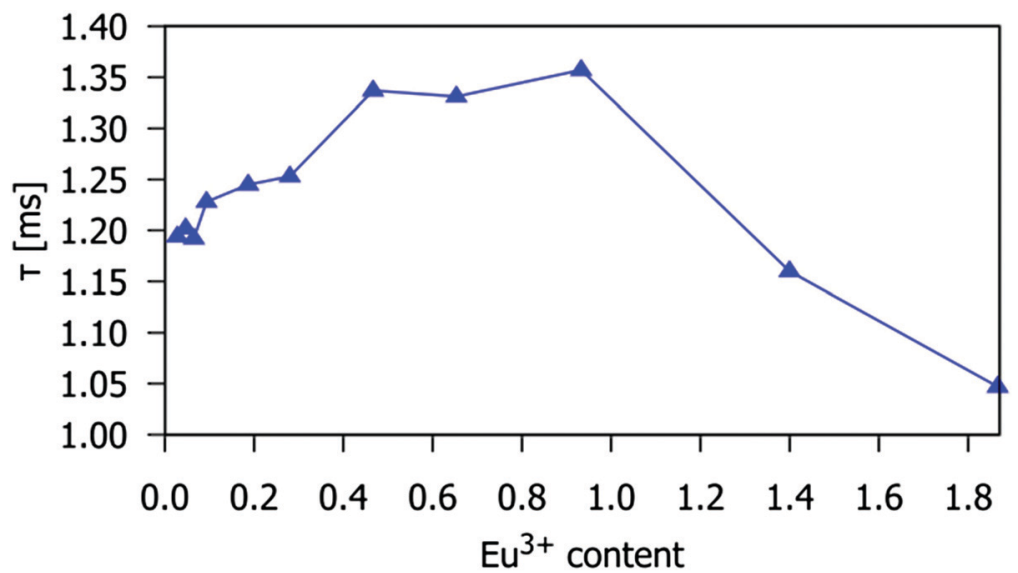

Fig. 6 The ${ }^{5} \mathrm{D}_{0}$ excited state lifetime of the $\mathrm{Eu}^{3+}$ ion in the $\mathrm{Gd}_{9.33-x} \mathrm{Eu}_{x}\left(\mathrm{SiO}_{4}\right)_{6} \mathrm{O}_{2}$ phosphors as a function of $x$. The temporal decay of the emission was monitored at $614 \mathrm{~nm}\left({ }^{5} \mathrm{D}_{0} \rightarrow{ }^{7} \mathrm{~F}_{2}\right.$ transition).

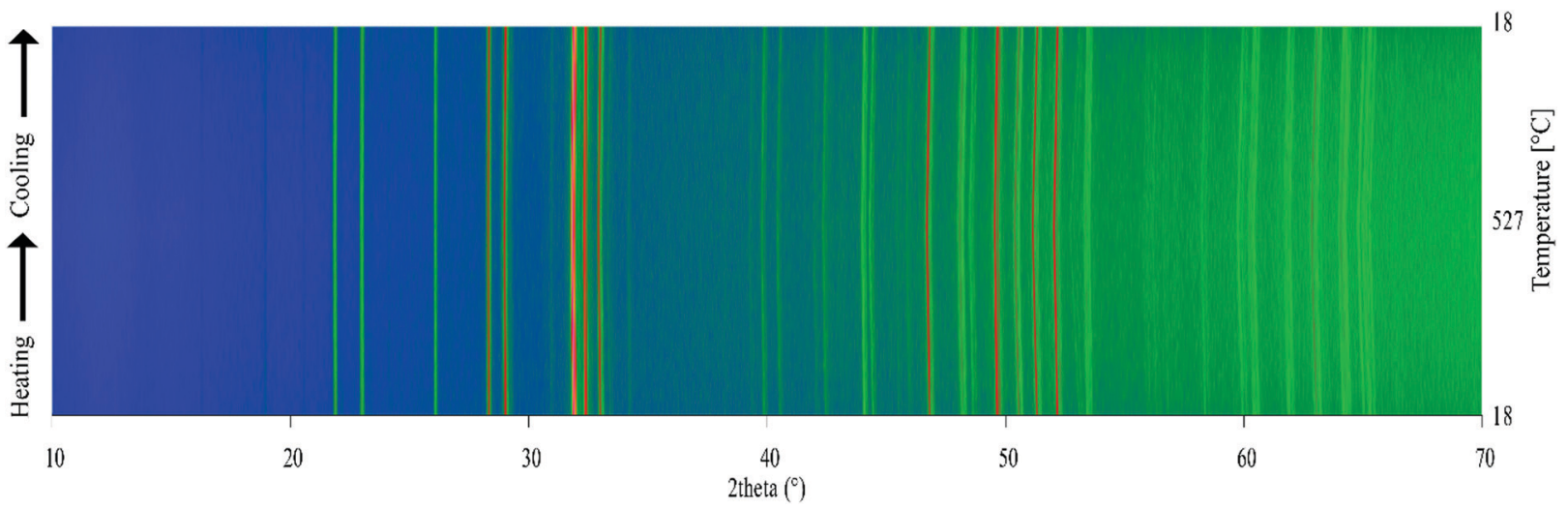

Fig. 7 Variable-temperature laboratory PXRD patterns for the $\mathrm{Gd}_{9.05} \mathrm{Eu}_{0.28}\left(\mathrm{SiO}_{4}\right)_{6} \mathrm{O}_{2}$ on warming and cooling between $18{ }^{\circ} \mathrm{C}$ and $527{ }^{\circ} \mathrm{C}$. The artificial colour map shows intensity changes in the PXRD pattern.

temperature, shown in with green, yellow and blue lines and symbols, has a linear positive thermal expansion trend (further details are given in Table S4, ESI $\uparrow$ ). Anisotropic thermal expansion in the host material causes subtle changes in the shape of the $\mathrm{Eu}^{3+}$ emission bands (Fig. 4a). The maximal splitting of the ${ }^{7} \mathrm{~F}_{1}$ manifold emission spectrum (marked as $\Delta E$ in Fig. 4a) is proportional to the crystal field strength acting on $\mathrm{Eu}^{3+}$. In the present case, $\Delta E \approx 320 \mathrm{~cm}^{-1}$ at room temperature, which is within the ranges reported in the literature for related red phosphors reported in the literature, e.g. $307-323 \mathrm{~cm}^{-1}$ for $\mathrm{Eu}_{2} \mathrm{Mo}_{3} \mathrm{O}_{12}$ and 350-374 cm ${ }^{-1}$ for $\mathrm{Y}_{2-x} \mathrm{Lu}_{x} \mathrm{O}_{3}: \mathrm{Eu}^{3+} \cdot{ }^{46,47}$ As the temperature increases, the unit cell of the host material becomes larger $(V$ is increasing) so the ligating ions are on average further from the $\mathrm{Eu}^{3+}$ centre and the intensity of the crystal field decreases. This effect is manifested by a decrease in the $\Delta E$ value at higher temperatures, as seen in Fig. 8 (where the data points are shown as red symbols and the fit as the red line).

The PL emission spectra of $\mathrm{Gd}_{9.05} \mathrm{Eu}_{0.28}\left(\mathrm{SiO}_{4}\right)_{6} \mathrm{O}_{2}$ recorded under $532 \mathrm{~nm}$ excitation at several different temperatures in the range $0-500{ }^{\circ} \mathrm{C}$ are shown in Fig. 9. Splitting of the emission line is observed at room temperature due to $\mathrm{Eu}^{3+}$ being located at two different crystallographic sites. Furthermore, broadening is observed as the temperature increases. This is related to more pronounced lattice vibrations at higher temperatures.

The normalised emission integrals obtained from the emission spectra are shown in Fig. 10 (normalised to the maximum intensity value obtained from the spectrum measured at $25^{\circ} \mathrm{C}$ ). At $150{ }^{\circ} \mathrm{C}$, the normalised emission integral only decreases to $90 \%$ of its room temperature value. Hence, the $\mathrm{Gd}_{9.05} \mathrm{Eu}_{0.28}\left(\mathrm{SiO}_{4}\right)_{6} \mathrm{O}_{2}$ phosphor presents good thermal quenching characteristics. This behaviour is superior to that reported in the literature for $\mathrm{NaSrEu}\left(\mathrm{MoO}_{4}\right)_{3}$ which decreased to $64 \%$ at $150{ }^{\circ} \mathrm{C}^{48}$ To determine the activation energy of the thermally induced emission quenching process, the experimental data were fitted to the configurational coordinate charge transfer (CT) model: ${ }^{49}$

$$
I_{\mathrm{CT}}(T)=\frac{I_{0}}{1+\frac{B}{\sqrt{\frac{h \nu}{2 k_{\mathrm{B}}}} \operatorname{coth}\left(\frac{h \nu}{2 k_{\mathrm{B}} T}\right)} \exp \left(\frac{-2 \Delta E_{\mathrm{CT}}}{h \nu} \tanh \left(\frac{h \nu}{2 k_{\mathrm{B}} T}\right)\right)} .
$$




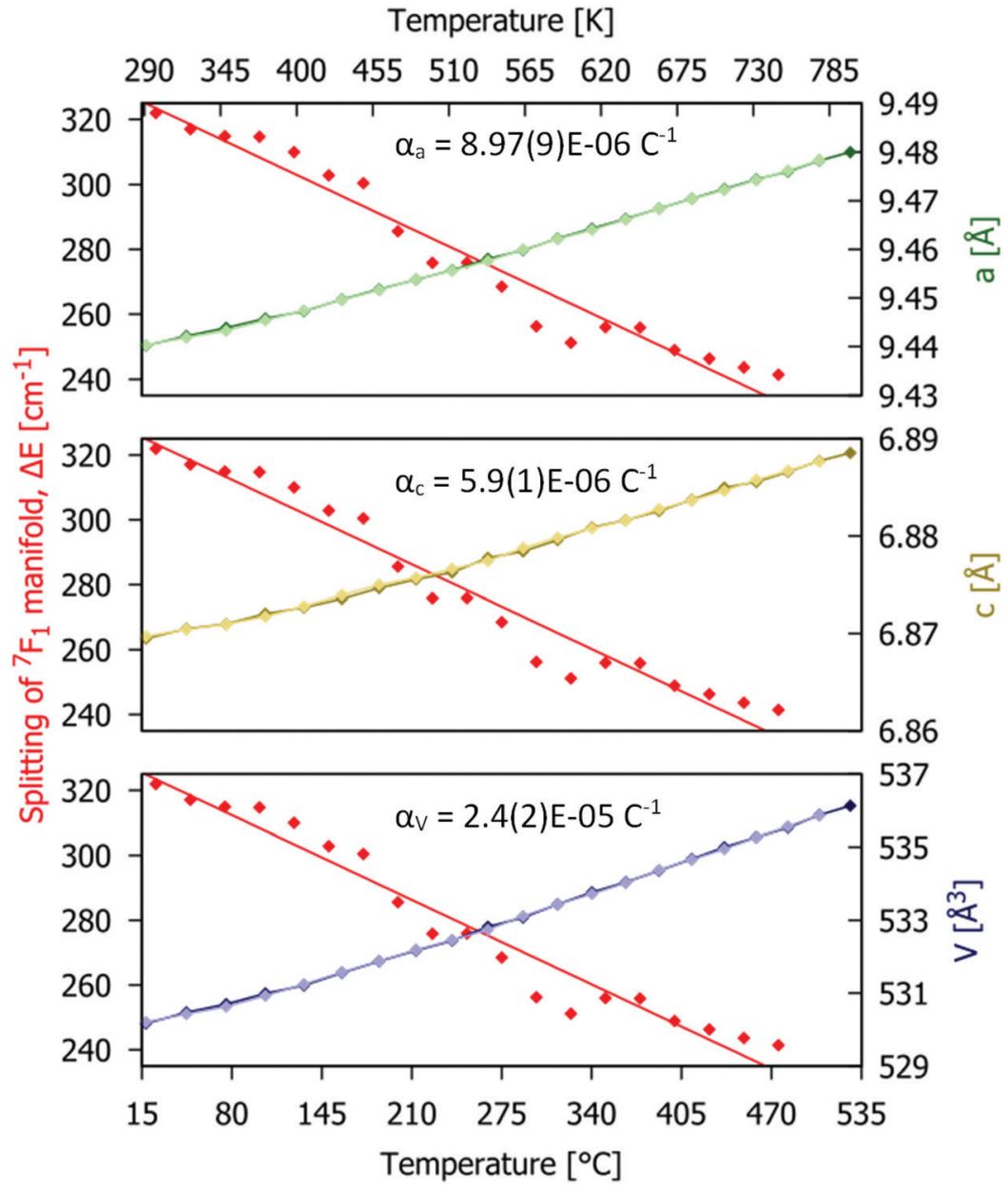

Fig. 8 Temperature dependences of structural parameters (obtained from the Rietveld fit for PXRD data; green, red and blue symbols and line) and maximal energy splitting $\Delta E$ of the $\mathrm{Eu}^{3+}{ }^{5} \mathrm{D}_{0} \rightarrow{ }^{7} \mathrm{~F}_{1}$ manifold (data as red symbols and fit as red lines) for the $\mathrm{Gd}_{9.05} \mathrm{Eu}_{0.28}\left(\mathrm{SiO}_{4}\right)_{6} \mathrm{O}_{2} \mathrm{phosphor}_{\text {. }}$

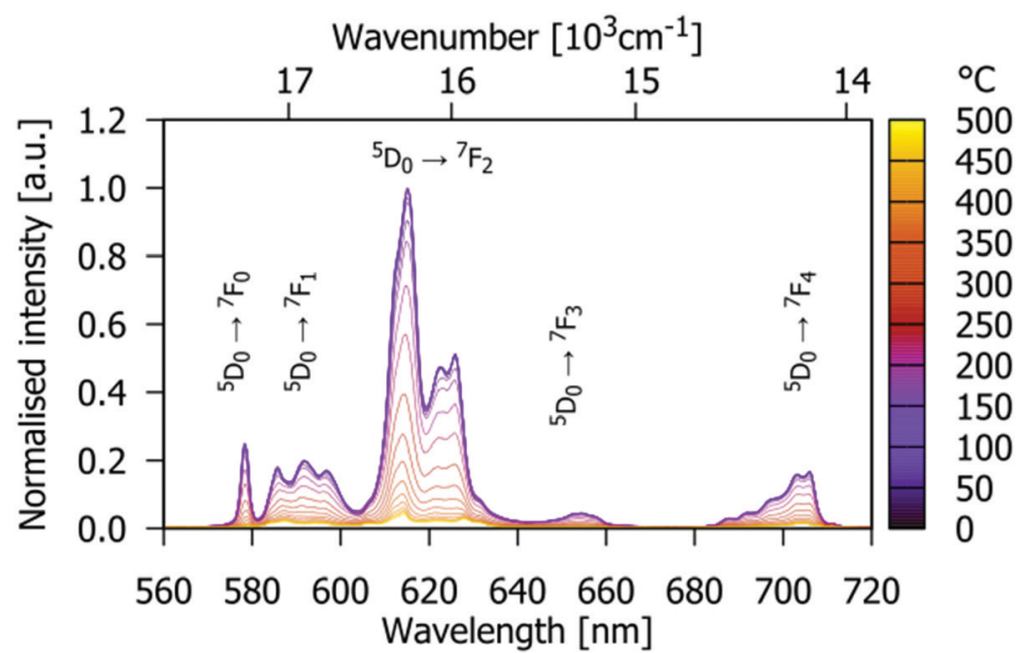

Fig. 9 Temperature-dependent $\mathrm{PL}$ emission spectra of the $\mathrm{Gd}_{9.05} \mathrm{Eu}_{0.28}\left(\mathrm{SiO}_{4}\right)_{6} \mathrm{O}_{2}$ phosphor (excited by $532 \mathrm{~nm}$ radiation). Colour scale marks the temperature from $25^{\circ} \mathrm{C}$ (purple) to $475^{\circ} \mathrm{C}$ (yellow).

Here, $I_{\mathrm{CT}}(T)$ is the temperature-dependent emission integral, $B=k_{\mathrm{NR}} / k_{\mathrm{R}}$ is the ratio of the non-radiative and radiative $I_{0}=1$ is the value of the emission integral at room temperature, transition rates, $\Delta E_{\mathrm{CT}}$ is the energy of the intersection between 


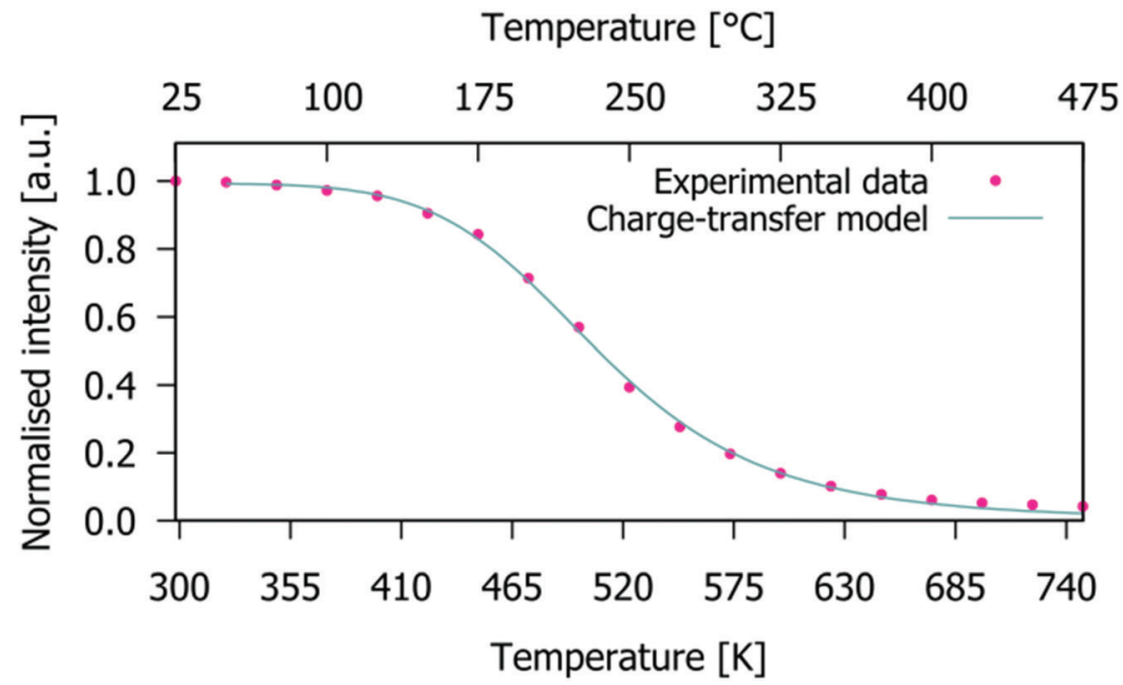

Fig. 10 Charge-transfer model fit (solid line) for temperature-dependent emission integrals of the experimental data (dots) for the $\mathrm{Gd}_{9.05} \mathrm{Eu}_{0.28}\left(\mathrm{SiO}_{4}\right)_{6} \mathrm{O}_{2}$ phosphor (integral values are normalised to that obtained from the spectrum measured at $25^{\circ} \mathrm{C}$ ).

parabolas that represent the charge-transfer state and ${ }^{5} \mathrm{D}_{0}$ state in the configuration coordinate representation, $k_{\mathrm{B}}$ is the Boltzmann constant $\left(8.617342 \times 10^{-5} \mathrm{eV} \mathrm{K}^{-1}\right)$, and $h v$ is the average energy of host phonons involved in the process.

The charge-transfer model fit of the experimental temperature-dependent emission integrals (solid line and symbols, respectively, in Fig. 10) for the $\mathrm{Gd}_{9.05} \mathrm{Eu}_{0.28}\left(\mathrm{SiO}_{4}\right)_{6} \mathrm{O}_{2}$ phosphor leads to a value for the activation energy of the emission thermal quenching process of $0.54(1) \mathrm{eV}$. This energy is a measure of the thermal stability of the $\mathrm{Eu}^{3+}$ emission; higher activation energies describe phosphors with high thermal stability of emission. The obtained value of gadolinium silicate apatite is superior to the values of $0.412 \mathrm{eV}$ for $\mathrm{Sr}_{4} \mathrm{La}_{6}\left(\mathrm{SiO}_{4}\right)_{6} \mathrm{~F}_{2}: \mathrm{Eu}^{3+},{ }^{22} 0.481 \mathrm{eV}$ for $\mathrm{Sr}_{4} \mathrm{La}_{6}$ $\left(\mathrm{SiO}_{4}\right)_{6} \mathrm{C}_{12}: \mathrm{Eu}^{3+},{ }^{22} 0.4(1) \mathrm{eV}$ for $\mathrm{Eu}_{2} \mathrm{Mo}_{4} \mathrm{O}_{15},{ }^{50}$ but lower than that of $0.84(4) \mathrm{eV}$ for $\mathrm{Tb}_{2} \mathrm{Mo}_{3} \mathrm{O}_{12}: \mathrm{Eu}^{3+}$. ${ }^{36}$

\subsection{Judd-Ofelt analysis of the intensities of the electronic transitions in $\mathrm{Gd}_{9.33-x} \mathrm{Eu}_{x}\left(\mathrm{SiO}_{4}\right)_{6} \mathrm{O}_{2}$}

The Judd-Ofelt (JO) theory allows for the quantitative analysis of $\mathrm{f}-\mathrm{f}$ electronic transitions of lanthanide ions and provides the JuddOfelt intensity parameters $\left(\Omega_{2}\right.$ and $\left.\Omega_{4}\right)$, the value of radiative lifetime and the intrinsic quantum yield. ${ }^{51,52}$ The $\Omega_{2}$ and $\Omega_{4}$ parameters, as well as the relationship between both parameters, demonstrate the nature and extent of bonding of the $\mathrm{Eu}^{3+}$ with the ligands and the degree of asymmetry around the metal ion site. ${ }^{53}$ For $\mathrm{Gd}_{9.33-x} \mathrm{Eu}_{x}\left(\mathrm{SiO}_{4}\right)_{6} \mathrm{O}_{2}$ phosphors, the JO intensity parameters $\Omega_{2}$ and $\Omega_{4}$, shown in Fig. 11 were calculated from the respective emission spectra using JOES software ${ }^{36}$ (see the ESI, $\dagger$ Section S1 for details of calculation) and assuming the refractive index to be $1.8 .^{54}$

The $\Omega_{2}$ parameter is strongly dependent on the ${ }^{5} \mathrm{D}_{0} \rightarrow{ }^{7} \mathrm{~F}_{2}$ transition rate and on the symmetry around $\mathrm{Eu}^{3+} \cdot{ }^{55,56}$ Fig. 11

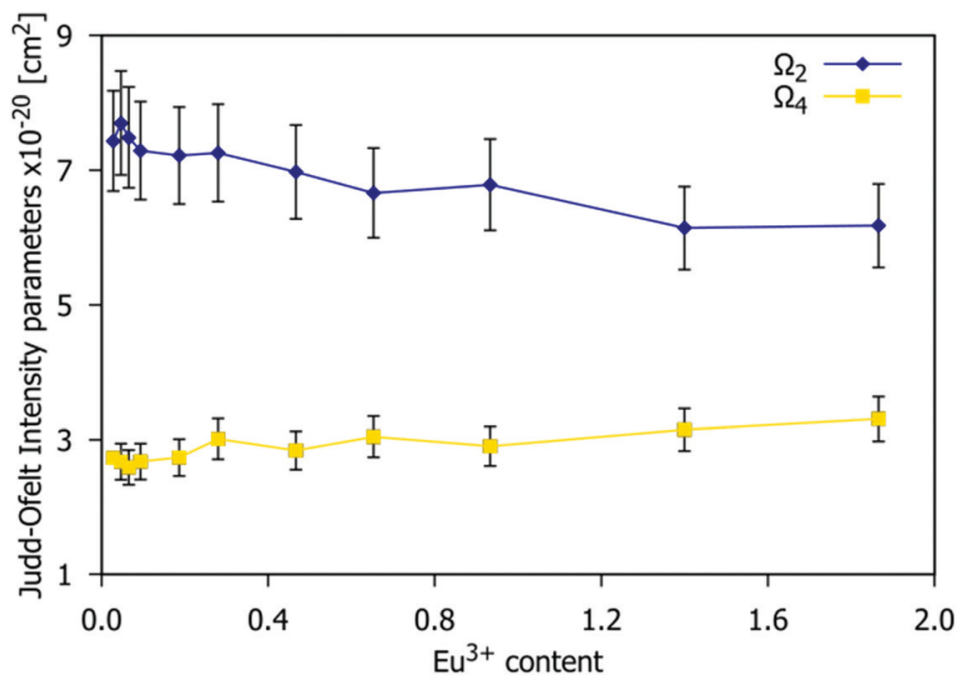

Fig. 11 Values of the Judd-Ofelt $\Omega_{2}$ and $\Omega_{4}$ intensity parameters estimated from the emission spectra as a function of the Eu ${ }^{3+}$ concentration of the $\mathrm{Gd}_{9.33-x} \mathrm{Eu}_{x}\left(\mathrm{SiO}_{4}\right)_{6} \mathrm{O}_{2}(0.03<x<1.87)$ phosphors. 


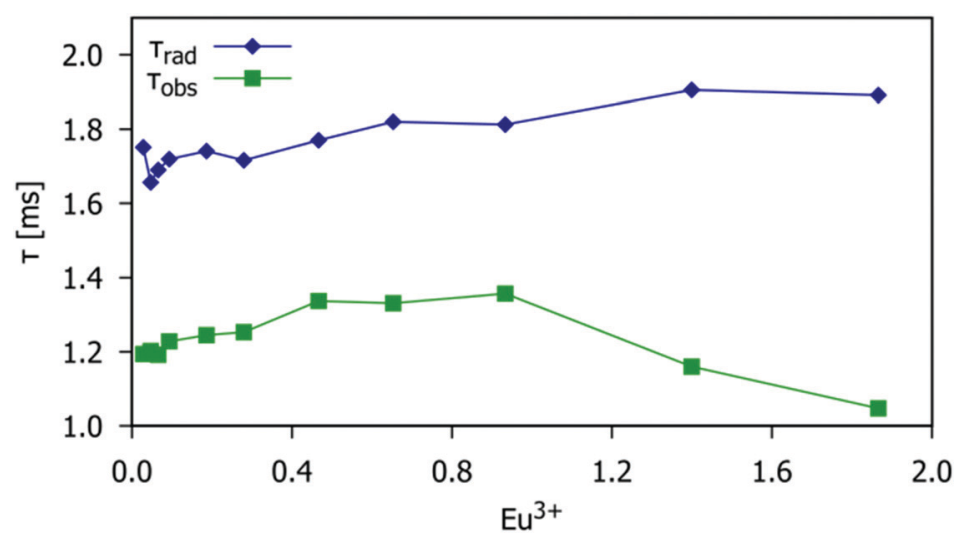

Fig. 12 The radiative and experimentally observed lifetimes (blue and green data points respectively) as a function of the Eu ${ }^{3+}$ doping level for the $\mathrm{Gd}_{9.33-x} \mathrm{Eu}_{x}\left(\mathrm{SiO}_{4}\right)_{6} \mathrm{O}_{2}$ phosphors $(0.03<x<1.87)$.

shows that the $\Omega_{2}$ value decreases when the $\mathrm{Eu}^{3+}$ doping content increases, which implies a decrease in the average distortion of the $\mathrm{Eu}^{3+}$ cation coordination polyhedra and perhaps a reduction in covalent nature..$^{53}$ As stated previously, the available crystallographic sites for $\mathrm{Eu}^{3+}$ are $4 \mathrm{f}$ and $6 \mathrm{~h}$ with $C_{3}$ and $C_{\mathrm{S}}$ symmetry respectively. The decrease of $\Omega_{2}$ shown in Fig. 11 suggests that the higher local symmetry site $\left(C_{3}\right)$ is preferentially occupied at higher $\mathrm{Eu}^{3+}$ concentrations. This is consistent with the arrangements found in other series of phosphors based on the apatite structure type, such as $\mathrm{A}_{2} \mathrm{Y}_{8}\left(\mathrm{SiO}_{4}\right)_{6} \mathrm{O}_{2} \quad(\mathrm{~A}=\mathrm{Ca}, \mathrm{Sr}) .{ }^{57}$ The values obtained range from $6.9(7)$ to $6.2(6) \times 10^{-20} \mathrm{~cm}^{2}$, which is in accordance with those reported in the literature for $\mathrm{Sr}_{0.2} \mathrm{Ca}_{9.65} \mathrm{Eu}_{0.1}$ $\left(\mathrm{PO}_{4}\right)_{6}(\mathrm{OH})_{2},{ }^{56} \Omega_{2}=6.68 \times 10^{-20} \mathrm{~cm}^{2} ; \mathrm{Ca}_{9.5} \mathrm{Eu}_{0.5}\left(\mathrm{PO}_{4}\right)_{6}(\mathrm{OH})_{2},{ }^{58}$ $\Omega_{2}=6.85 \times 10^{-20} \mathrm{~cm}^{2}$; and $\mathrm{Sr}_{9.95} \mathrm{Eu}_{0.05}\left(\mathrm{PO}_{4}\right)_{6}(\mathrm{OH}){ }^{59} \Omega_{2}=6.83 \times$ $10^{-20} \mathrm{~cm}^{2}$.

The $\Omega_{4}$ value is dependent on the ${ }^{5} \mathrm{D}_{0} \rightarrow{ }^{7} \mathrm{~F}_{4}$ transition (emission peak at $705 \mathrm{~nm}$ ). This parameter is related to the viscosity and rigidity of the matrix. In Fig. $11, \Omega_{4}$ experiences a small increase with an increasing $\mathrm{Eu}^{3+}$ concentration. The values obtained range from 2.3(2) to $2.7(3) \times 10^{-20} \mathrm{~cm}^{2}$. $\Omega_{6}$ was not calculated as the very weak emission arising from the ${ }^{5} \mathrm{D}_{0} \rightarrow{ }^{7} \mathrm{~F}_{6}$ transition is out of the measurement range of our device.

The observed lifetimes, $\tau_{\text {obs }}$, were measured following the procedure described in the Experimental section. The natural radiative lifetimes, $\tau_{\text {rad }}$, were calculated from the total spontaneous emission rate constant, $\tau_{\mathrm{obs}}{ }^{-1}$. Fig. 12 shows a comparison of the lifetime values as a function of the $\mathrm{Eu}^{3+}$ doping level. The difference in value between radiative and observed lifetimes represents the non-radiative lifetime, $\tau_{\mathrm{obs}}{ }^{-1}=\tau_{\mathrm{rad}}{ }^{-1}+\tau_{\mathrm{nrad}}{ }^{-1}$. The value of radiative lifetime slightly increases with the increase in $\mathrm{Eu}^{3+}$ doping concentration, Fig. 11 (blue symbols) due to small variations in symmetry around $\mathrm{Eu}^{3+}$ which is consistent with the previous discussion of the $\Omega_{2}$ value change with $\mathrm{Eu}^{3+}$ doping concentration (Fig. 10). However, the increase in $\mathrm{Eu}^{3+}$ concentration causes an increase in the non-radiative rate (i.e. the decrease in the non-radiative lifetime, $\left.\tau_{\text {nrad }}\right)$ due to the energy migration between $\mathrm{Eu}^{3+}$. This effect becomes pronounced for $\mathrm{Eu}^{3+}$ concentrations larger than the critical concentration $(x=0.93)$ when the average distance between activator ions is small enough for the dipole-dipole mechanism to become significant. Then, the observed lifetime, Fig. 11 (red symbols) starts to decrease. The results of JO calculations are thus consistent with the analysis of the temperatureinduced emission quenching discussed in Section 3.4.

The intrinsic quantum efficiency of $\mathrm{Eu}^{3+}$ emission, $\eta$, was calculated (see the ESI, $\uparrow$ Section S1 for details of calculation) for the different $\mathrm{Eu}^{3+}$ doping concentrations as given in Table 2. The highest intrinsic emission efficiency of $75 \%$ is found for $x=$ 0.93 , in agreement with the threshold for concentration quenching (note that JO theory may overestimate the value of quantum yield, but by no more than $10 \%{ }^{60}$ ). The values listed in Table 2 are comparable to those reported in the literature for other apatite-type materials, e.g. $\eta=63 \%$ for $\mathrm{Ca}_{9.9} \mathrm{Eu}_{0.1}$ $\left(\mathrm{PO}_{4}\right)_{6}(\mathrm{OH})_{2},{ }^{61} \eta=62 \%$ for $\mathrm{Ca}_{9.85} \mathrm{Eu}_{0.1}\left(\mathrm{PO}_{4}\right)_{6} \mathrm{~F}_{2},{ }^{62}$ and $\eta=66 \%$ for $\mathrm{Ca}_{9.95} \mathrm{Eu}_{0.05}\left(\mathrm{PO}_{4}\right)_{6}(\mathrm{OH})_{2}{ }^{58}$

Fig. 13 shows the temperature dependence of the JO $\Omega_{2}$ and $\Omega_{4}$ parameters (the limitation of the calculation is the assumption that the refractive index is independent of temperature). ${ }^{63}$ Values were obtained for each temperature in $25{ }^{\circ} \mathrm{C}$ steps from $25{ }^{\circ} \mathrm{C}$ to $475{ }^{\circ} \mathrm{C}$ (see Table S5, ESI $\dagger$ for numerical values). The $\Omega_{2}$ value remains almost constant up to $150{ }^{\circ} \mathrm{C}$ but then decreases rapidly with temperature. This increase of local symmetry is related to the higher disorder presented for the structure at high temperature, with the $\mathrm{Eu}^{3+}$ coordination polyhedra becoming more regular, and perhaps due to a reduction in covalency. The $\Omega_{4}$ parameter stays constant because the $\mathrm{Gd}_{9.05} \mathrm{Eu}_{0.28}\left(\mathrm{SiO}_{4}\right)_{6} \mathrm{O}_{2}$ structure is quite rigid and thermally stable (as confirmed by VT-PXRD), as expected for the apatite structure, and justifying the choice of this material as a phosphor host.

Table 2 Intrinsic efficiency of emission, $\eta$, for the $\mathrm{Gd}_{9.33-x} \mathrm{Eu}_{x}\left(\mathrm{SiO}_{4}\right)_{6} \mathrm{O}_{2}$ phosphors

\begin{tabular}{llllllllllll}
$x$ & 0.03 & 0.05 & 0.07 & 0.09 & 0.19 & 0.28 & 0.47 & 0.65 & 0.93 & 1.4 & 1.87 \\
\hline$\eta(\%)$ & 68 & 73 & 71 & 71 & 72 & 73 & 75 & 73 & 75 & 61 & 55
\end{tabular}




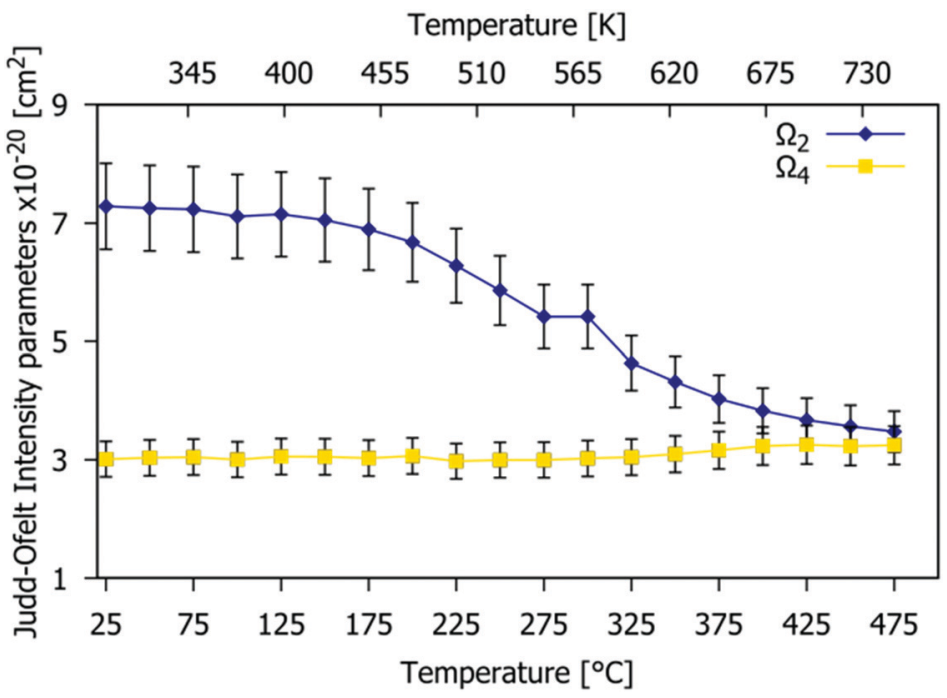

Fig. 13 Temperature-dependence of the $\Omega_{2}$ and $\Omega_{4}$ Judd-Ofelt intensity parameters estimated from the emission spectra of the $\mathrm{Gd}_{9.05} \mathrm{Eu}_{0.28}\left(\mathrm{SiO}_{4}\right)_{6} \mathrm{O}_{2}$ phosphor at different temperatures.

\section{Conclusions}

A new $\mathrm{Gd}_{9.33-x} \mathrm{Eu}_{x}\left(\mathrm{SiO}_{4}\right)_{6} \mathrm{O}_{2}(0.03<x<1.87)$ phosphor series based on apatite-type silicate host shows narrow-band red emission centred at $614 \mathrm{~nm}$, with exceptionally high colour purity of $94.2 \%$. The structure of the host, together with the reduction in the covalent character of the interaction of $\mathrm{Eu}^{3+}$ with the counterions with increasing temperature, confer excellent optothermal stability on this phosphor: the emission intensity is reduced by only $10 \%$ at $150{ }^{\circ} \mathrm{C}$ compared to room temperature. Thermal quenching of emission was modelled using the charge-transfer model, and the activation energy of the thermal quenching process was found to be $0.54(1) \mathrm{eV}$. The highest quantum yield of about $75 \%$ is achieved with the relatively high doping level of $10 \%$ of Eu. Such high efficiency is a consequence of the highly asymmetric crystallographic sites where the $\mathrm{Eu}^{3+}$ ions are located and the large distance between them. The latter means that concentration quenching does not occur significantly until relatively high dopant concentrations are reached ( $>10 \%$ of $\mathrm{Eu}$ ), beyond which electric dipole-dipole energy transfer between $\mathrm{Eu}^{3+}$ starts to compete with the radiative transition.

\section{Conflicts of interest}

There are no conflicts to declare.

\section{Acknowledgements}

Melissa M. Rodríguez-García (scholarship holder no. 607462) gratefully acknowledges the support of the Mexican Secretary of Energy that has been made thanks to CONACYT, financial support of SENER-CONACYT through the scholarship no. 447874. Authors from Serbia acknowledge support from the
Ministry of Education, Science and Technological Development of the Republic of Serbia.

\section{References}

1 K. Singh, M. Rajendran, R. Devi and S. Vaidyanathan, Dalton Trans., 2021, 50, 4986-5000.

2 R. Devi, K. Singh and S. Vaidyanathan, J. Mater. Chem. C, 2020, 8, 8643-8653.

3 M. Rajendran and S. Vaidyanathan, New J. Chem., 2020, 44, 14823-14836.

4 R. Devi, R. Boddula, J. Tagare, A. B. Kajjam, K. Singh and S. Vaidyanathan, J. Mater. Chem. C, 2020, 8, 11715-11726.

5 J. Brodrick, Solid-state lighting R\&D plan, US Department of Energy, 2016.

6 P. Morgan Pattison, M. Hansen and J. Y. Tsao, C. R. Phys, 2018, 19, 134-145.

7 J. Y. Tsao, M. E. Coltrin, M. H. Crawford and J. A. Simmons, Proc. IEEE, 2010, 98, 1162-1179.

8 J. M. Phillips, M. E. Coltrin, M. H. Crawford, A. J. Fischer, M. R. Krames, R. Mueller-Mach, G. O. Mueller, Y. Ohno, L. E. S. Rohwer, J. A. Simmons and J. Y. Tsao, Laser Photonics Rev., 2007, 1, 307-333.

9 K. Binnemans, Coord. Chem. Rev., 2015, 295, 1-45.

10 C. Görller-Walrand and K. Binnemans, in Handbook on the Physics and Chemistry of Rare Earths, Elsevier, 1998, vol. 25, pp. 101-264.

11 F. Baur and T. Jüstel, Opt. Mater.: X, 2019, 1, 100015.

12 X. He, D. Bian, H. Wang and J. Xu, Luminescence, 2013, 28, 973-976.

13 X. Zhang, L. Zhou, Q. Pang, J. Shi and M. Gong, J. Phys. Chem. C, 2014, 118, 7591-7598.

14 Y. C. Li, Y. H. Chang, B. S. Tsai, Y. C. Chen and Y. F. Lin, J. Alloys Compd., 2006, 416, 199-205.

15 J. Ding, Y. Li, Q. Wu, Q. Long, C. Wang and Y. Wang, J. Mater. Chem. C, 2015, 3, 8542-8549. 
16 X. Ma, L. Liao, Q. Guo, H. Liu, T. Zhou and L. Mei, RSC Adv., 2018, 8, 27332-27341.

17 N. Guo, Q. Liang, S. Li, R. Ouyang and W. Lü, Opt. Mater., 2017, 73, 570-576.

18 Y. Liu, Z. Wang, J. Zhong, F. Pan, H. Liang and Z. Xiao, Mater. Lett., 2014, 129, 130-133.

19 H.-S. Roh, S. Lee, S. Caliskan, C. Yoon and J.-K. Lee, J. Alloys Compd., 2019, 772, 573-578.

20 L. Li, W. Chang, W. Chen, Z. Feng, C. Zhao, P. Jiang, Y. Wang, X. Zhou and A. Suchocki, Ceram. Int., 2017, 43, 2720-2729.

21 Z. Fu, X. Wang, Y. Yang, Z. Wu, D. Duan and X. Fu, Dalton Trans., 2014, 43, 2819-2827.

22 L. Shi, S.-w. Zhao, Z. Ying, Y.-j. Han, M. Li, M.-y. Zhang and Z.-w. Zhang, J. Mater. Sci.: Mater. Electron., 2019, 30, 1803-1812.

23 P. Zhu, H. Zhu, W. Qin, B. H. Dantas, W. Sun, C.-K. Tan and N. Tansu, J. Appl. Phys., 2016, 119, 124305.

24 A. M. Latshaw, K. D. Hughey, M. D. Smith, J. Yeon and H.-C. zur Loye, Inorg. Chem., 2015, 54, 876-884.

25 M. M. Rodríguez-García, J. A. G. Williams and I. R. Evans, J. Mater. Chem. C, 2019, 7, 7779-7787.

26 S. Cui and G. Chen, Mater. Res. Express, 2019, 6, 096201.

27 A. S. de Oliveira, B. H. S. T. da Silva, M. S. Góes, A. Cuin, H. de Souza, L. F. C. de Oliveira, G. P. de Souza, M. A. Schiavon and J. L. Ferrari, J. Lumin., 2020, 227, 117500. 28 S. Li, M. Xu, L. Wang, D. Jia, N. Guo, C. Ji and H. Wu, Opt. Mater., 2020, 107, 110151.

29 N. Liu, L. Mei, L. Liao, J. Fu and D. Yang, Sci. Rep., 2019, 9, 15509.

30 K. Nie, X. Ma, P. Lin, N. Kumar, L. Wang and L. Mei, J. Rare Earths, 2020, DOI: 10.1016/j.jre.2020.10.019.

31 C. Zeng, Y. Hu, Z. Xia and H. Huang, RSC Adv., 2015, 5, 68099-68108.

32 G. Zhu, Y. Shi, M. Mikami, Y. Shimomura and Y. Wang, Opt. Mater. Express, 2013, 3, 229-236.

33 AXS Bruker, 2000.

34 H. M. Rietveld, J. Appl. Crystallogr., 1969, 2, 65.

35 A. A. Coelho, J. S. O. Evans, I. R. Evans, A. Kern and S. Parsons, Powder Diffr., 2011, 26, S22.

36 A. Ćirić, S. Stojadinović, M. Sekulić and M. D. Dramićanin, J. Lumin., 2019, 205, 351-356.

37 P. Du, X. Huang and J. S. Yu, Chem. Eng. J., 2018, 337, 91-100.

38 P. Du and J. S. Yu, RSC Adv., 2015, 5, 60121-60127.

39 P. Du and J. S. Yu, J. Mater. Sci., 2016, 51, 5427-5435.
40 J. Li, Q. Liang, Y. Cao, J. Yan, J. Zhou, Y. Xu, L. Dolgov, Y. Meng, J. Shi and M. Wu, ACS Appl. Mater. Interfaces, 2018, 10, 41479-41486.

41 Y.-L. Chen, J. Wang and G.-Q. Wang, Opt. Mater., 2020, 106, 110022.

42 M. Rajendran and S. Vaidyanathan, J. Alloys Compd., 2019, 789, 919-931.

43 G. Blasse, Philips Res. Rep., 1969, 24, 131-144.

44 D. L. Dexter, J. Chem. Phys., 1953, 21, 836-850.

45 L. Van Uitert, J. Electrochem. Soc., 1967, 114, 1048.

46 F. Baur, F. Glocker and T. Jüstel, J. Mater. Chem. C, 2015, 3, 2054-2064.

47 Ž. Antić, R. Krsmanović, M. Wojtowicz, E. Zych, B. Bártová and M. D. Dramićanin, Opt. Mater., 2010, 32, 1612-1617.

48 M. Rajendran and S. Vaidyanathan, Dalton Trans., 2020, 49, 9239-9253.

49 R. Englman and J. Jortner, J. Lumin., 1970, 1, 134-142.

50 M. Janulevicius, J. Grigorjevaite, G. Merkininkaite, S. Sakirzanovas and A. Katelnikovas, J. Lumin., 2016, 179, 35-39.

51 B. R. Judd, Phys. Rev., 1962, 127, 750-761.

52 G. S. Ofelt, J. Chem. Phys., 1962, 37, 511-520.

53 M. G. Brik, A. Zcaron, M. Eljka, K. Vukovic and M. D. Dramicanin, Mater. Trans., 2015, 56, 1416-1418.

54 S. S. Batsanov, E. D. Ruchkin and I. A. Poroshina, Refractive Indices of Solids, Springer, 2016, pp. 51-56.

55 F. Auzel, J. Alloys Compd., 2004, 380, 9-14.

56 P. Sobierajska and R. J. Wiglusz, New J. Chem., 2019, 43, 14908-14916.

57 T. Jansen, T. Justel, M. Kirm, H. Magi, V. Nagirnyi, E. Toldsepp, S. Vielhauer, N. M. Khaidukov and V. N. Makhov, J. Lumin., 2017, 186, 205-211.

58 K. Szyszka, J. Rewak-Soroczynska, A. Dorotkiewicz-Jach, K. A. Ledwa, A. Piecuch, M. Giersig, Z. Drulis-Kawa and R. J. Wiglusz, J. Inorg. Biochem., 2020, 203, 110884.

59 K. Zawisza and R. J. Wiglusz, Dalton Trans., 2017, 46, 3265-3275.

60 R. Rolli, K. Gatterer, M. Wachtler, M. Bettinelli, A. Speghini and D. Ajo, Spectrochim. Acta, Part A, 2001, 57, 2009-2017.

61 R. J. Wiglusz, A. Bednarkiewicz, A. Lukowiak and W. Strek, Spectrosc. Lett., 2010, 43, 333-342.

62 P. Sobierajska, R. Pazik, K. Zawisza, G. Renaudin, J.-M. Nedelec and R. J. Wiglusz, CrystEngComm, 2016, 18, 3447-3455.

63 A. Ćirić, S. Stojadinović and M. D. Dramićanin, Phys. B, 2020, 579, 411891. 